NLW

$112,9 / 10$

406

Received 20 January 2011

Reviewed 4 March 2011

\section{REFEREED ARTICLE Public libraries and the national minorities of Sweden - results of a national survey}

\author{
Joacim Hansson \\ Department of Library and Information Science, School of Cultural Studies, \\ Linnaeus University, Växjö, Sweden
}

\begin{abstract}
Purpose - The purpose of the paper is to report the findings of a Swedish national survey study finalised in late 2010. The purpose of the project was to create a picture of Swedish library services directed to the five minority groups defined as "national minorities" in the country: Romani, Sámi, Jews, Tornedalians and Swedish Finns. The study focuses on media, cultural activities, and co-operation.

Design/methodology/approach - In the study, a survey questionnaire was used as the primary method. The questionnaire was sent to all 289 county libraries of Sweden. A total of 181 were returned and used in the study. The theoretical stance is emancipatory in that it takes the position that libraries may play a vital role not only for the social integration of the concerned minority groups, but also for spreading interest in, and understanding of, the unique identities of these groups in the majority society.

Findings - The findings of the study show that Swedish public libraries have very limited services towards the national minority groups in focus. In some cases, like service to the elderly and out-reach activity, no activity whatsoever could be measured.

Originality/value - The research reported in the article is original in that it is the first time that the services to the national minority groups of Sweden are mapped and measured at a national level. The value of the result is high as it shows major weaknesses in library services and the study provides a good point of departure for developing minority services in Swedish libraries.
\end{abstract}

Keywords Public libraries, Ethnic minorities, Sweden, Critical theory

Paper type Research paper

The project "Biblioteken och de nationella minoriteterna" ("Libraries and national minorities") was co-funded by the Swedish Library Association and the department of Library and Information Science at Linnaeus University, Växjö, Sweden. The study consisted of a survey sent by mail to each of Sweden's 289 county libraries in October-November 2009. By the end of the year 181 usable questionnaires had been returned.

Questionnaires were worked out jointly by the Swedish Library Association (SLA) and the Department of Library and Information Science at the Linnaeus University. The SLA collected the questionnaire, while the LIS department conducted the analysis during January-March 2010. The final report was published and presented in Swedish by the SLA in September 2010 (Ahlryd et al., 2010). In October 2010 a national seminar on libraries and national minorities was arranged in Stockholm by the SLA, and a final presentation and discussion of the results was held at the SLA annual national conference in May 2011, in Visby.
New Library World

Vol. 112 No. 9/10, 2011

pp. $406-415$

(C) Emerald Group Publishing Limited 0307-4803

DOI $10.1108 / 03074801111182003$ 


\section{Introduction}

In her studies on political and ideological development Belgian political theorist Chantal Mouffe $(2000,2005)$ argues that the contemporary political landscape, not least in Europe, is increasingly building upon a consensus model in which all marginalised groups of citizens are seen either as "included" in the general liberal political framework, or simply seen as superfluous and disturbing. There is no real room for the kind of tension that real ethnic diversity has the potential of promoting in a society a potential that also is a prerequisite for a vital democracy. The very concept of democracy requires what Mouffe discusses as "legitimate conflicts" between different groups in society. The vitality of a democracy that accepts and builds upon such differences of interests between its ethnic groups is, by Mouffe, called "agonistic pluralism". Such legitimate conflicts can be promoted by public libraries (Hansson, 2010). In most countries public libraries promote and visualise social tensions by displaying the different interests found in the variety of ethic groups, both nationally and locally. The way in which this is done, however, differs as do the priority between promoted groups. Different ethnic groups are "valued" differently either by general prejudice or by legislative protection. We know very little of how these conscious and unconscious values influence ethnic minority work in libraries.

The aim of this article is to analyse attitudes and activities among Swedish public libraries towards ethnic minorities. Groups in focus are five specific minorities that have been given special protection by the Swedish state and that thus are defined as "national" minorities. Based on Mouffe's concept of agonistic pluralism, results from a national survey study are presented, focusing on the following three areas:

(1) media and acquisition - collection development about national minority groups and in their respective language;

(2) cultural activities directed towards and about national minority groups; and

(3) co-operation with organisations outside the library.

A complementary point of departure is taken in library and information studies, which has shown and discussed the complexity of ethnic minority work in public libraries. Often such work is prioritised and related to a general role in society for libraries as "meeting places" (Aabø et al., 2010) or supporting local initiatives of social integration and democratic participation (Elbeshausen and Skov, 2007; Swedish Library Association, 2008; Flintoff, 2006). One problem in this research has been to actually define the meeting place-concept and show how libraries actually work in this regard. Another problem is that studies often accept the consensual point of view criticised by Mouffe. Discussions on integration are being made on the conditions set by the social and political majority rather than on that of those groups in focus for various integration activities. Looking at the practice in public libraries, however, many activities are badly funded and little interest for the library needs of minority groups are acknowledged by funding agencies and patrons (which in terms of tax funding can be described as the ethnic majority of the citizens). We also know that many librarians experience insecurity when approaching groups whose patterns of behaviour or preferences differ from those of the social majority (Muddiman et al., 2001; Pateman and Vincent, 2010). Even though these latter studies have been carried out in the UK, there is no reason to assume that the same problems would not be present in other countries, including Sweden. The fact that social stratification and concrete political

\section{Public libraries} of Sweden 
NLW

$112,9 / 10$

408 measures to meet the need of social consensus and integration differ does not change that the basic mechanisms of their consequences for a vital democratic development are more or less similar.

\section{Background: Sweden's minority policy and the national minorities}

The official policy concerning national minorities in Sweden is based on the Framework Convention for the protection of National Minorities (FCNM), decided upon by the European Council in February 1995. The text of the convention does not stipulate what specific ethnic groups are to be given the status of "national minority", instead it only provides a very wide territorial and cultural heritage oriented definition, leaving it to each nation to choose what groups are relevant for the proposed protection.

The Swedish government decided in 1999 which groups should be defined as "national minorities". A national minority shall, according to the government decision, be an ethnic group which is clearly separated from the majority of the population through religion, language, tradition and culture. Individuals belonging to this group shall also share a will to preserve and develop the unique identity of the group. The group should also have been present in Swedish society for a long period of time - the government here set a random time limit at the year 1900. The decision thus defined five distinctive minority groups as "national minorities":

(1) the Sámi people, also defined as indigenous;

(2) the Romani people;

(3) the Jewish people;

(4) the Swedish Finns; and

(5) the Tornedalians, the meänkieli speaking population of the Tornio Valley on the northern border of Sweden and Finland.

Of these, the Swedish Finns is the by far largest group, and also the one which has been most integrated into the majority society.

The overall aim of the legislation concerning national minorities is to define the kind of support that is to be given in order for them to be able to maintain their cultural identities. Five major areas are given priority:

(1) education;

(2) cultural policy;

(3) mass media;

(4) archives; and

(5) elderly care.

Of these, at least four have a potential for including explicit library activities. Even though libraries are not mentioned anywhere, they should - only by looking at the legislative texts - be able to play a central role in fulfilling the ambitions of the government in creating the best possible circumstances for the national minorities in Sweden. As an important aspect of supporting these groups is preserving and developing their languages - Sami languages[1], Romani Chib, Jiddish, Finnish and Meänkieli - it is clear that the potential of libraries is implicit. However, as 
responsibility for carrying through public support to the minority groups is delegated all the way down to county level, it is hard to get a clear picture, at a national level, on how the protection is actually being managed in practice.

\section{The mandate of public libraries}

The only authorities or public agencies mentioned in the government are the courts, pre-schools and publicly funded elderly homes. In the northern part of Sweden, these are obliged to offer services in the Sami, Finnish and Miänkieli languages when asked for.

Libraries are not mentioned and do thus not have any such formal obligations. In the Swedish library law from 1996, none of the national minority groups are mentioned. In its eighth paragraph however, there is a sentence on immigrant groups and minorities in general:

$8 \S$ Public libraries and school libraries shall prioritise the physically impaired, immigrants and other minorities, e.g. by offering literature in other languages than Swedish and in forms suiting the needs of these groups/Auth. translation/.

Focus is directed towards distribution of literature. There is no mention of other kinds of activities, such as general cultural activities and programmes that can contribute to local identity building and integration. The national minorities are not given any priority in relation to any other ethnic minority or immigrant group, and if looking at how libraries work with these latter groups, it is clear that local initiative and projects often trigger activities and that the local presence of specific groups is an overall determining factor. The offering of literature in languages other than Swedish is also mostly connected to the local existence of certain immigrant or minority groups. The idea of keeping foreign languages literature just "for the sake of it" is not defended by any library today.

Studies conducted in Sweden show a very clear pattern. The presence of media directed towards one or more of the national minorities - in their language or not - is directly linked to the local representation of these groups (Vikman, 2004). Various forms of cultural and language support activities also increased when libraries work towards local groups, such as Sámi people (Björkman and Liljedahl, 2009) and Romani and Jewish minorities (Vigur and Finnberg, 2009). Still the level of activities reported in these studies is relatively low. What seems clear is that librarians often feel uncertain about what kind of support different groups need. The special position of the national minorities in relation to other minority groups seems to be pretty much unknown in many libraries, thus very little discussion on how to meet these groups takes place (Jennische, 2004).

\section{The study: results}

The empirical study consisted of a questionnaire distributed to public libraries in all 289 counties in Sweden. A total of 181 surveys were completed and thus provide the basis of the analysis. Questions were divided in three parts: media and acquisition; cultural activities directed at specific user groups; and co-operation with agents outside the own library. All three parts gave room for comments that could specify the answers in the questionnaire. Due to the character of the statistical distribution of the answers, these comments have provided an important basis for analysis when trying to achieve an understanding for the answers given.

\section{Public libraries} of Sweden 
NLW

$112,9 / 10$

410

\section{Media and acquisition}

The libraries answered questions on how much media they have, directed to each of the national minority groups. They were also asked the numbers of acquisitions in 2008 and 2009. The term "media" was not narrowly defined, but could consist both of media about the minority groups and media published in any of the national minority languages. Comments added to the questions here from the informants suggested that the vast majority of new media that was defined as directed towards the national minority groups were books and periodicals in their own respective languages.

\section{Cultural activities}

One group of questions focused on whether libraries offered cultural activities of any kind, focusing the national minority groups. Activities included were, among others, literary evenings, recitals, film showings, exhibitions and concerts. Questions were also asked about activities specifically directed towards special groups within the national minority population. Two groups, children and the elderly, were distinguished in the questionnaire.

\section{Co-operation}

The last batch of questions asked if libraries co-operated with others when planning media purchases and cultural activities. It was not specified with whom or how this co-operation would take place. However, two institutions were singled out as being more interesting than others; existing special libraries and minority organisations.

\section{Media and acquisition}

The total amount of media directed to any of the concerned minority groups in public libraries at a national level was in 2009 118,550 units. Allocation of media resources between the different groups is asymmetrical; the Swedish Finns have 93 per cent of the total resources. The second biggest group, the Sámi, is represented by just fewer than 5 per cent.

Looking at acquisitions the picture is almost identical: 3,493 units of new media were acquired nationally during 2008 and 2009, and the Swedish Finns dominate completely with 93 per cent of the bought media. This domination by the Swedish Finnish group in relation to the others can be understood by three main factors:

(1) The Swedish Finns is the by far largest group of the national minorities in Sweden. It is reasonable and hardly surprising that it has a considerably higher number of media than do the others.

(2) When answering the questionnaire, librarians have most likely been generous when defining what media to include into the group of Swedish Finns. Here is not only literature in Finnish, but also, probably, much of the literature covering the common history of Sweden and Finland. There are also numerous journals and newspapers produced for this group in Sweden.

(3) The Swedish Finns live all over the country, and the fact that their historical presence in large industrial cities still holds, make them well represented in big libraries with substantial media acquisitions. 


\section{Cultural activities}

In this second main area too, a certain room for interpretation was allowed in defining what activities should be included. Two categories of activities were defined: those directed toward the specific minority group itself, and those concerning the minority, but being directed towards the majority community. Even so, the results show that as much as 95 per cent of the county libraries in Sweden have not engaged in any activities concerning national minority groups during 2008 and 2009 in any way whatsoever.

The level of disengagement is shown in the reported level of activity for the elderly and for children - the lack of activities directed towards children is approaching 100 per cent (we have a range between 97-99 per cent non-activities depending on group). It is difficult to distinguish one group from another - there is no evident difference between any of the national minority groups. The fact for instance that the Swedish Finns are not more visible in this area than any of the other groups is might be ascribed the same factors that showed them as so totally dominant in the media purchase - they are so prevalent in Swedish society that they are hard to distinguish from the majority population, making them part of "ordinary" cultural activities, and thus activities that "need" to be directed towards them are scarce.

The "extreme"...

On one issue, numbers of "nothingness" reached 100 per cent for all groups but the Swedish Finns - outreach activities. Outreach activities has a long tradition in Swedish public libraries, but as cut-backs have struck and ideologies changed, the idea of working outside the library building with under-privileged groups have simply fallen out of fashion or possibilities - most likely both. When we see that the Swedish Finns is the only group that is subject of any outreach activity whatsoever, it is a truth with some twist. Outreach activities are seen directed to this group in four out of the 181 responding counties, all four responding to the alternative "very little" activity.

These are of course dramatic figures. In whatever way the figures are turned on this, the only conclusion we can draw is that there is no interest at all in Sweden's public libraries to prioritise the national minorities when planning and carrying through cultural activities. If there were, outreach activities would be such a natural place to start where we would most probably see different figures on this matter.

\section{Co-operation}

Asking about the kinds of co-operation in which libraries engage in when turning towards the national minority groups, a number of factors complicate the picture. As in previous areas it was left open for respondents to define what was meant by the term co-operation. It was important to catch as many aspects of this as possible. In whatever way it is defined, however, co-operation between local libraries and outside actors or organisation showed to be scarce. This is hardly surprising, of course, given the limited work done in general towards the national minorities. The issue of what was defined as co-operation also played a part. We noted that, for instance, inter-library lending from, e.g. the Jewish Library in Stockholm to a local county library did not count as co-operation. If however the same library is consulted for selection and acquisition of media or planning local cultural activities, then it could count.

Two sets of questions were asked, regarding co-operation within the library sector (special libraries), and co-operation outside of the library sector (primarily minority

\section{Public libraries of Sweden}


NLW

$112,9 / 10$

412

groups and organisations). In both some co-operation was noted regarding the Sámi group and the Swedish Finns. In both of these 7 per cent of the responding libraries reported activities. Of the respondents, 8 per cent reported that they co-operated with Romani organisations, although none reported use of the Romani special library in Malmö.

This result does not deviate from the other parts of the study, but the result shows that there is an awareness of existing organisations and a noted potential in working together with these when creating suitable library services. When co-operating with minority organisations the situation is furthermore complicated by the simple fact that initiatives for working together not only can be expected to come from the local libraries. There are no studies, in Sweden anyway, yet showing how minority organisations - or citizens belonging to minority groups - see the local public library as a factual or potential partner for developing local identity and integration. The issue has, however, been studied in Denmark (Aarhus Public Libraries, 2001)

\section{Conclusion}

The point of departure of this study was taken from the concept "agonistic pluralism", where the vitality of democratic societies can be seen in their ability to promote and accept legitimate conflicts between different groups. Another point of departure was knowledge achieved within library and information science research of the level of complexity characterising work with ethnic minorities in public libraries. The study focused on five ethnic minorities that can be seen as highly valued by Swedish society. A sign of this is that they have been given specific legislative protection and are labelled "national minorities". In whatever way we choose to interpret the responses to the distributed questionnaire, there is no way around the fact that Swedish public libraries have an extraordinary limited activity towards these national minorities. This goes for collection development, out-reaching activities and co-operation alike. The reasons for this are not all easy to grasp - several factors influence the current situation. The result of the survey provides an overview, and does not focus on the qualitative analysis of these factors, but it does show a few signs pointing out in which direction to look.

The Swedish library law does not mention the national minorities, which makes it easy for libraries to argue that these groups need not to be prioritised. As libraries today are forced to be increasingly market oriented it becomes natural that they only engage in activities which, in one way or another, can be defined as directly (and visibly) demanded by the local population. The fact that the little activity that, despite all, is being carried out concerning the national minorities is exclusively in counties with a visible representation of one group or more is a clear result of this.

Activities are seen more in the north of Sweden where two of the groups, the Sámi and the Tornedalians, are well represented. The Jewish and the Romani groups are mostly represented in the larger cities such as Stockholm and Malmö, which is also reflected in the result of the study. The most difficult group to grasp is the Swedish Finns. Not only is it the by far largest group among the national minorities, but it is also geographically spread all over the country making is more visible in the data of the study than the others. It is, however, the group that is most difficult for libraries to single out in relation to specific tasks and activities, as many Swedish Finns are so assimilated that their needs for library services in many cases coincide with those of the majority population. 
The kinds of activities being directed towards the national minorities vary. The most common way of meeting the needs of minority groups is to offer a shelf containing literature on the group's language. According to comments given in several questionnaires, librarians wanted to limit their engagement towards the minorities to be focused on language preservation, in terms of offering minority language media. This is an approach that can be described as "traditional" also in an international point-of-view (Dilevko and Dali, 2002; Henczel, 2003; Blomqvist, 2007; Ericsson, 2009; Kesten, 2009). Much attention has also, on a general political level, been given to language related issues (Hyltenstam and Milani, 2004). Some respondents even reported having trouble approaching the survey when asked about the minority groups as "user groups" on the same terms as any other, something which has also been noted in Olsson (2009). Some libraries, notably in larger cities, offered occasional theme weeks and exhibitions directing focus not only on the groups themselves, but on the majority population as well. Even at a national level, however such offers can only be characterised as singular.

Looking at the responses county by county it is clear that work which is being carried out for the national minorities in Sweden is both well thought through and adapted to the needs of the local representation of these groups. It is, of course, not reasonable to expect of any library that activities should be immediately directed towards user groups that do not exist locally, national minorities being no exception. However, it is equally reasonable to find activities working with minority issues on a broader level and, when it comes to the national minorities, introducing, presenting and discussing them as parts of the Swedish self-image and as part of the Swedish cultural heritage. This is being done practically nowhere.

The character of the unique histories of each of the national minority groups, and their different relations toward Swedish mainstream culture provide a good example of "practical" agonistic pluralism. All groups have a history of tension between, on the one hand, the want and need to be accepted and included, and on the other, the need to uphold their ethnical sovereignty. These are the kinds of tensions that public libraries could visualise, partly on the basis of their general role in society, and partly as defined by relevant legislation. Engaging in critique and well-informed discussion on the multi-cultural character of Sweden that is actually there is one of the democratically most important issues that public libraries can do. They have a unique capability to envisage the complexity of society and prioritising groups with special legislative protection as being defined as key parts in Swedish cultural tradition and development should be seen as obvious in every level of public librarianship. The result of this study provides a background for discussion concerning these issues.

\section{Note}

1. There are, depending on how one counts, between nine and 11 distinct Sami languages. Of these, at least six are spoken in Sweden.

\section{References}

Aabø, S., Audunson, R. and Vårheim, A. (2010), "How do public libraries function as meeting places?”, Library \& Information Science Research, Vol. 32 No. 1, pp. 16-26.

Aarhus Public Libraries (2001), "Refuge for integration: a study of how the ethnic minorities in Denmark use the libraries", Aarhus Public Libraries, Aarhus, available at: http://gl.aakb.

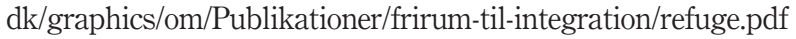

\section{Public libraries of Sweden}

413 
NLW

$112,9 / 10$

414

Ahlryd, S., Vigur, L. and Hansson, J. (2010), Biblioteken och de nationella minoriteterna - hur svenska folkbibliotek arbetar för romer, judar, tornedalingar, samer och sverigefinnar (Libraries and National Minorities - How Swedish Public Libraries Approach Romani, Jews, Tornedalians, Sami People and Swedish Finns), Swedish Library Association, Stockholm.

Björkman, P. and Liljedahl, H. (2009), Ett försvinnande inhemskt språk: En studie av de svenska folkbibliotekens roll för att revitalisera det sydsamiska språket (A Disappearing Domestic Language: A Study of the Role of the Swedish Public Libraries in Revitalising the Southern Sami Language), Växjö University, Växjö.

Blomqvist, T. (2007), Många språk - många möjligheter eller många svårigheter? Folkbibliotekens försörjning av böcker och tidskrifter på andra språk än svenska i Uppsala (Many Languages - Many Possibilities or Many Difficulties? Public Libraries' Provision of Books and Journals in Other Languages than Swedish in Uppsala), Uppsala University, Uppsala.

Dilevko, J. and Dali, K. (2002), "The challenge of building multilingual collections in Canadian public libraries", Library Resources \& Technical Services, Vol. 46 No. 4, pp. 116-38.

Elbeshausen, H. and Skov, P. (2007), "Public libraries in a multicultural space: a case study of integration processes in local communities", New Library World, Vol. 105 Nos 3-4, pp. 131-41.

Ericsson, C. (2009), Internationella bibliotekets flerspråkiga webbplats. Att tillgängliggöra maingkulturell biblioteksverksamhet på webben (The Multilingual Web-site of the International Library: Distributing Multi-cultural Library Services on the Web), University College of Borås, Borås.

Flintoff, H.F. (2006), "Towards inclusion - views on the school library's role in removing barriers to achievement for ethnic minority pupils: proactive, reactive, inactive? A small-scale study in Basingstoke's secondary school", New Review of Children's Literature and Librarianship, Vol. 12, pp. 83-102.

Hansson, J. (2010), "Chantal Mouffe's theory of agonistic pluralism and its relevance for library and information science research", in Leckie, G., Given, L. and Buschman, J. (Eds), Critical Theory in Library and Information Science: Exploring the Social from Across the Disciplines, Library Unlimited, Santa Barbara, CA, pp. 249-57.

Henczel, S. (2003), "Selecting and acquiring library materials in languages other than English: establishing non-English collections for public, school and academic libraries", Collection Building, Vol. 22 No. 3, pp. 141-5.

Hyltenstam, K. and Milani, T.M. (2004), Nationella minoriteter och minoritetsspråk. Uppföljning av Sveriges efterlevnad av Europarådets konventioner på nationell nivå: ett minoritetsspråksperspektiv (National Minorities and Minority Languages: Evaluation of Sweden's Compliance to the Conventions of the European Council on A National Level: A Minority Language Perspective), Rapport för konstitutionsutskottet, Centrum för tvåspråkighetsforskning, Stockholm.

Jennische, R. (2004), De nationella minoriteterna och folkbiblioteken: om folkbibliotekens hantering av nationella minoritetsfrågor $i$ ljuset av Sveriges officiella minoritetspolitik (The National Minorities and Public Libraries: On Public Libraries' Treatment of National Minority Issues in the Light of the Official Minority Policy of Sweden), Uppsala University, Uppsala.

Kesten, M. (2009), Medier på andra språk än svenska: En studie om det mångkulturella biblioteket (Media in Other Languages Than Swedish: A Study of the Multi-cultural Library), University College of Borås, Borås.

Mouffe, C. (2000), The Democratic Paradox, Verso, London.

Mouffe, C. (2005), On the Political, Routledge, Abingdon. 
Muddiman, D., Durrani, S., Dutch, M., Linley, R., Pateman, J. and Vincent, J. (2001), "Open to all? The public library and social exclusion: executive summary", New Library World, Vol. 102 Nos 1163/1164, pp. 154-7.

Olsson, N. (2009), "The living library. Rhetorics concerning prejudices and encounters. An argumentation analysis in relation to the multicultural assignment of public libraries", Det levande biblioteket. Retorik kring fördomar och möten. En argumentationsanalys $i$ relation till folkbibliotekens mångfaldsuppdrag, University college of Borås, Borås.

Pateman, J. and Vincent, J. (2010), Public Libraries and Social Justice, Ashgate, Farnham.

Swedish Library Association (2008), Framgångsrikt, men förbisett: om bibliotekens betydelse för integration (Successful, But Overlooked: On the Significance of Libraries in Social Integration), Swedish Library Association, Stockholm.

Vigur, L. and Finnberg, K. (2009), Mer än Katitzi och klezmer?: en kvalitativ undersökning av biblioteksverksamhet riktad mot romer och judar (More than Katitzi and Klezmer? A Qualitative Study of Library Services Towards Romani and Jews), Växjö University, Växjö.

Vikman, M. (2004), Sveriges nationella minoriteter: En studie av deras tillgång till tidskrifter vid Sveriges folkbibliotek (The National Minorities of Sweden: A Study of their Access to Journals in Swedish Public Libraries), Uppsala University, Uppsala.

\section{Corresponding author}

Joacim Hansson can be contacted at: joacim.hansson@lnu.se

\section{Public libraries of Sweden}

415

To purchase reprints of this article please e-mail: reprints@emeraldinsight.com Or visit our web site for further details: www.emeraldinsight.com/reprints 